\title{
REFORMA OU REVOLUÇÃO NA FILOSOFIA POLÍTICA DE HEGEL, A VIA PRUSSIANA E A VIA FRANCESA PARA A REALIZAÇÃO DA RAZÃO'
}

\author{
REFORM OR REVOLUTION IN HEGEL'S POLITICAL PHILOSOPHY: THE \\ PRUSSIAN WAY AND THE FRENCH WAY FOR THE REALIZATION OF REASON
}

\author{
JOHN AQUINO² \\ Universidade Federal do Ceará (UFC) - Brasil \\ johnksousa@gmail.com
}

\begin{abstract}
RESUMO: Para Hegel quando as normas e instituições existentes não preservam nem promovem mais a liberdade, mas limitam e atrasam seu desenvolvimento, perdem sua razão de ser e torna-se uma necessidade histórica a correção dessas normas e instituições positivas de acordo com as exigências históricas da razão. Para o filósofo quando o direito positivo precisa ser corrigido, essa correção pode ser realizada pelos "de cima", que para Hegel seria quando o próprio governo realiza as mudanças necessárias, na figura do monarca, ou a correção pode ser realizada pelos "de baixo", na figura histórica do povo, como aconteceu na França em 1789. A primeira forma de correção seria a reforma e a segunda seria a revolução. Na presente pesquisa tentaremos definir qual o posicionamento político de Hegel diante das reformas e das revoluções que inauguraram o mundo moderno.
\end{abstract}

PALAVRAS-CHAVE: Hegel. Reforma. Revolução.

ABSTRACT: For Hegel, when existent norms and institutions do not preserve or foment liberty but limit and delay its development, they lose their reason for being. It then becomes a historical necessity to correct these norms and positive institutions according to the historical requirements of reason. For the philosopher, when the positive right needs to be corrected, this correction can be made "from above", which for Hegel would be when the government itself makes the necessary changes in the figure of the monarch, or the correction can be performed "from below," as happened in France in 1789. The first form of correction would be reform and the second would be revolution. In the present research we will try to define the political position of Hegel in the face of the reforms and revolutions that inaugurated the modern world.

KEYWORDS: Hegel. Reform. Revolution.

\footnotetext{
${ }^{1}$ Este artigo é a última parte do capítulo III da dissertação do autor, intitulada "Racionalidade e efetividade do Direito em Hegel: normatividade e historicidade da liberdade", disponível em: http://www.repositorio.ufc.br/bitstream/riufc/22184/3/2017_dis_jksaquino.pdf.

2 Professor do Instituto Federal de Educação, Ciência e Tecnologia do Ceará (IFCE/ Campus Itapipoca) e doutorando em Filosofia da Universidade Federal do Ceará (UFC).
} 


\section{INTRODUÇÃO}

O objetivo desse artigo é tentar solucionar a questão que acompanha a trajetória de Hegel desde os anos de 1810, a saber, qual seria o posicionamento político de Hegel? Seria ele um pensador reacionário comprometido com os objetivos restauracionistas da Santa Aliança? Seria ele um teórico politicamente conservador, empenhado em justificar o status quo pós-revolucionário? Ou Hegel estaria vinculado a projetos políticos de "esquerda", sejam esses projetos de viés reformista ou revolucionário? ${ }^{3}$ Pretendemos responder essa questão a partir da leitura dos escritos de Hegel sobre os acontecimentos históricos por ele tematizados em sua Filosofia da História e do seu último escrito Ueber die Englische Reformbill, de 1831.

Hegel viveu em um período conturbado e explosivo da história europeia. Tudo que até então fora tido como verdadeiro, como inviolável e sagrado estava sendo derrubado pela força das armas ou por decretos parlamentares, reis estavam sendo depostos e o povo surgia como protagonista histórico capaz de transformar a realidade ${ }^{4}$. Pela primeira vez na história o homem sabia que a realidade objetiva não era independente dele, mas dependente de sua vontade e ação, que o mundo histórico era resultado da prática individual e coletiva do sujeito.

A Revolução Francesa é o principal acontecimento histórico da época de Hegel, é o ponto de referência não só da sua filosofia, mas de todo o idealismo alemão5. Para Hegel a Revolução Francesa resultou da tomada de consciência do povo francês de que o direito positivo, as normas e instituições existente, não satisfaziam as exigências da liberdade, "o princípio da liberdade da vontade fazse então valer contra o direito existente" (HEGEL, 2008, p. 365) ${ }^{6}$. Segundo ele a

\footnotetext{
${ }^{3}$ A primeira leitura, a de um Hegel reacionário é a de Rudolf Haym em Hegel und seine Zeit, a de um Hegel conservador é típica da leitura marxista, enquanto a leitura de um Hegel de "esquerda", reformista e as vezes quase revolucionário são a de Domenico Losurdo e a de Herbert Marcuse.

4 "Em nenhum momento mais do que hoje, a compreensão do senso comum (der allgemeine Verstand) foi levada a distinguir entre os direitos meramente positivos em seu conteúdo real, e aqueles direitos que também são em si e por si mesmos racionais" (HEGEL, 2009, \$5).

5 "O idealismo alemão foi considerado a teoria da Revolução Francesa. Isto não significa que Kant, Fichte, Schelling e Hegel tenham elaborado uma interpretação teórica da revolução francesa, mas que, em grande parte, escreveram suas filosofias em resposta ao desafio vindo da França à reorganização do Estado e da sociedade em bases racionais, de modo que as instituições sociais e políticas se ajustassem à liberdade e aos interesses do indivíduo. Apesar de sua severa crítica ao terror, os idealistas alemães saudaram unanimemente a Revolução, considerando-a o despontar de uma nova era, e, sem exceção, associaram seus princípios filosóficos básicos aos ideais que ela promovera" (MARCUSE, 1978, p. 17).

${ }^{6}$ Segundo Marcuse a Revolução Francesa significou para os idealistas alemães, e principalmente para Hegel, o atestado histórico de que o ser humano havia finalmente atingido sua maioridade, se emancipando das autoridades externas e fez de seu julgamento racional o critério para avaliação e correção do mundo, "a revolução francesa, aos olhos dos idealistas alemães, não só abolira o absolutismo feudal, substituindo-o pelo sistema econômico da classe média, mas, ao emancipar o indivíduo como senhor autoconfiante de sua vida, completara o que a Reforma Alemã havia começado. A situação do homem no mundo, seu trabalho e lazer, deveriam,
} 
realidade francesa era um atentado contra a razão, o direito positivo em vez de preservar e promover a liberdade, apenas garantia a manutenção dos privilégios de poucos e o Estado havia sido diminuído à condição inadequada de patrimônio privado de uma classe social parasitária, que consumia as finanças públicas com festas e outras formas de esbanjamento desnecessárias.

Toda a situação da França naquela época é, na verdade, um agregado de privilégios contra o pensamento e a razão, uma situação absurda, à qual está ligada toda a perversidade dos costumes e do espírito - um reino da injustiça, que se torna, com a conscientização da mesma, uma injustiça vergonhosa. A terrível pressão sofrida pelo povo e o descaso do governo, permitindo na corte a opulência e o esbanjamento, foram os primeiros motivos para a insatisfação (grifo nosso) (HEGEL, 2008, p. 365).

A tomada de consciência de que o modo como as coisas estavam estabelecidas não era racional, e por isso injustificável, permitiu que o povo francês compreendesse que o direito positivo não lhes correspondia ao direito racional, que as normas e instituições francesas quando corretamente avaliadas demonstravam o quanto o estado de coisas existente era inaceitável para qualquer indivíduo minimamente racional. Segundo Hegel,

Com isso, foi encontrado um princípio intelectual, para servir de base ao Estado, que não é mais um princípio qualquer da opinião - como o ímpeto da sociabilidade, a necessidade de segurança da propriedade, etc. - nem o da religiosidade - como a instituição divina da autoridade mas é o princípio da certeza, a identidade com minha autoconsciência [...] (Ibidem).

A discrepância entre o sabido e o feito foi a causa maior da Revolução Francesa na perspectiva idealista de Hegel. O povo francês consciente de seus direitos e consciente de que o direito positivo não atendia tais direitos, mas pelo contrário, os contrariava, tomou para si a tarefa histórica de realizar a razão. Evidentemente o povo francês não estava consciente de que sua ação iria ter um impacto histórico mundial, não sabiam que sua ação muito mais do que libertálos de um governo opressivo e da miséria material instauraria um direito positivo baseado no direito racional e garantiria o progresso na realização da liberdade. Em síntese, o povo francês não sabia que estava realizando os objetivos da razão, para os protagonistas da revolução eles estavam apenas lutando para garantir seus interesses.

Segundo Hegel, na França, à beira da revolução, um "novo espírito começou a agitar as mentes dos homens, e a opressão levou-os à investigação. Descobriu-se então que as quantias extorquidas do povo não eram utilizadas no aprimoramento do Estado, mas gastas da forma mais absurda. Todo o sistema do

doravante, depender de sua própria atividade racional e livre e não de qualquer autoridade externa. O homem superara o longo período de imaturidade, durante o qual fora oprimido por esmagadoras forças naturais e sociais, e se tornara sujeito autônomo de seu próprio desenvolvimento" (grifo nosso) (MARCUSE, 1978, p. 17). 
Estado manifestava-se como uma injustiça" (Ibidem). Nesse contexto dois sujeitos poderiam realizar as mudanças necessárias e atender as demandas da razão, o povo francês ou o governo francês na figura de Luís XVI. A incapacidade ou falta de vontade do governo em realizar as mudanças exigidas pela razão deixou como única alternativa o protagonismo popular e foi exatamente por isso que as mudanças aconteceram de forma radical, porque foram os "de baixo", foi o povo, que realizou todas as mudanças necessárias de uma só vez. Devido à inércia dos "de cima", diz Hegel, "a mudança foi necessariamente violenta, porque a transformação não partiu do governo, e ela não foi iniciativa do governo porque a corte, o clero, a nobreza e o parlamento não queriam abdicar de seus privilégios, nem por necessidade, nem pelo direito em si; (grifo nosso)" (Ibidem, p. 365-366). Consciente de que as coisas não podiam continuar do jeito que estavam o povo francês diante da inoperância do Rei em efetivar as mudanças tomou para si essa responsabilidade histórica e fez valer as exigências da razão e assim "a ideia, o conceito de direito, finalmente se fez valer, e aqui a antiga estrutura da injustiça não pôde mais resistir" (Ibidem, p. 366). Foi pela força das armas, através da violência, que a razão se efetivou na França e no mundo.

Porém, como já foi dito, não é apenas pela revolução, pela ação dos "de baixo" que a razão pode se efetivar, ela também ocorre pela decisão dos "de cima", mais especificamente por decisão do príncipe, as mudanças exigidas pela razão podem ser efetivadas.

Outro elemento ainda mais importante na transformação da lei (Recht) deve ser mencionado, ou seja, a ampla visão dos príncipes na tomada de decisões relacionadas ao bemestar do Estado, a felicidade de seus súditos e a prosperidade geral - mas, sobretudo, o sentido de uma justiça, que tem de ser em si e para si - para o esclarecimento da atividade legislativa, em associação com o devido realce do monarca, de modo a obter a aceitação destes princípios e convertê-los em realidade perante privilégios meramente positivos, de longa data baseados no interesse privado e na incompreensão das massas (HEGEL, 2009, \$6).

Para Hegel dois sujeitos políticos e históricos têm interesses em realizar as mudanças necessárias para o progresso da liberdade, "esse interesse partia tanto dos reis como do povo" (HEGEL, 2008, p. 354), as mudanças efetuadas pelo primeiro seriam as reformas ou "mudanças por alto" e as mudanças do segundo seriam as revoluções ou "mudanças por baixo". No contexto da época, o filósofo identifica as forças conservadoras, o termo particular do silogismo político, no estamento aristocrático e na Igreja, dois atores políticos que teriam o interesse em conservar em vez de transformar o status quo, contrariando as mudanças exigidas pela razão. Desse modo, na avaliação de Hegel, "no sentido de que, segundo a análise por ele realizada, na contradição entre príncipe, de um lado, e 'povo', de outro, o progresso também pode ser representado pelo príncipe. Esse é um ponto firme da sua filosofia da história" (LOSURDO, 1998, p. 157). 
Quando é o próprio governo que se responsabiliza em atender as demandas da razão, avaliando e corrigindo o direito positivo, as mudanças são graduais e não imediatas, pacíficas e não violentas. Não é imperativa a intervenção do povo que inevitavelmente conduz à revolução e a todos seus excessos, mas tudo é feito pacientemente e sem recurso à violência excessiva, mediante decretos e decisões do governo, através de reformas, evitando o risco da revolução. Ou seja, para Hegel caso o Rei Luís XVI tivesse feito o que tinha que fazer, combatendo os interesses particulares do clero e da nobreza, corrigindo o direito positivo conforme as demandas da razão, não teria ocorrido a revolução, mas uma reforma.

\section{II}

No seu último escrito intitulado Sobre a Reforma eleitoral britânica de 1831, Hegel defende que essas duas formas de realizar a razão, a revolução e a reforma, correspondem respectivamente à solução adotada pelos franceses em 1789 e a solução adotada pela Alemanha, ou mais especificamente a Prússia do final do século XVIII e início do século XIX. Segundo ele os monarcas e parlamentos da época tinham duas opções diante de si: ou realizavam as mudanças necessárias, através de reformas, como fizeram os prussianos, ou permaneciam na inércia e o povo realizava as mudanças necessárias através da revolução, como fizeram os franceses. Nesse seu último escrito Hegel indica claramente que as reformas são preferíveis às revoluções. ${ }^{7}$

Para Hegel todas as conquistas de uma revolução podem ser obtidas através de uma reforma, mas sem perigos, sem violência, e de forma lenta e gradual, sem os imediatismos radicais próprios da revolução. Para Hegel apesar dos efeitos mais demorados e indiretos da reforma, a mesma teria o mesmo resultado das revoluções, mas em ritmo mais lento e sem recurso à violência. Assim, enquanto uma revolução efetua todas as mudanças de uma só vez e seus efeitos são imediatos, a reforma efetua as mudanças necessárias aos poucos e seus efeitos são em longo prazo. As reformas seriam efetuadas pelos "de cima" e não pelos "de baixo", seriam protagonizadas pelo príncipe, e não pelo povo.

Segundo Rosenfield, Hegel se estabeleceu na Universidade de Berlim em 1818, a convite de Karl Sigmund von Altenstein (ROSENFIELD, 2005, p. 24). Nesse período o governo prussiano era composto por políticos e militares reformistas, dedicados a desenvolver uma constituição para a Prússia, substituindo a monarquia absolutista por uma monarquia constitucional. Os reformistas prussianos pretendiam reformar o direito marcadamente feudal por um direito mais moderno, de acordo com os princípios do jusnaturalismo moderno. Esse gabinete convidou Hegel para assumir a cátedra de filosofia da Universidade de Berlim, assim como também o convidou para compor a Comissão Examinadora da Real Academia de Brandemberg, responsável por

\footnotetext{
7 "Hegel era orgulhoso das reformas que foram iniciadas em toda Alemanha por vários grupos de burocratas após 1789. Assim ele é um defensor do que os estudiosos da história alemã chamam de 'revolução por cima" (HEGEL, 2009, p. 321, rodapé 20, nota dos editores).
} 
realizar uma reforma do currículo das escolas secundárias (PLANT, 2000, p. 18; ROSENFIELD, 2005, p. 24).

Nos diversos principados e ducados que compunham a então inexistente Alemanha, está posta a missão histórica de reconstruir o governo e a administração após o fim da era napoleônica e é nesse momento que "se coloca aqui uma questão que vai presidir toda a história alemã, e mesmo para além dela, a saber, a dos agentes dessa reconstrução, sem que o processo desemboque numa guerra civil, numa revolução ou no descontrole político da situação" (ROSENFIELD, 2011, p. 93). Para os reformadores alemães, e Hegel é um deles, a solução passa por desviar-se da "via francesa", "para os reformadores alemães, a reforma na Alemanha não seria feita nos moldes da Revolução francesa, mas seria de cima para baixo, a partir do próprio Estado" (Ibidem, p. 93-94).

Quando Hegel se estabelece em Berlim o governo prussiano está dividido em duas tendências, "em duas correntes básicas: a reformista e a dos feudais, dos nobres e dos setores da corte. A primeira, capitaneada por Hardenberg, é a mais influente até sua morte em 1822" (ROSENFIELD, 2005, p. 24). Hegel se filia justamente a essa tendência reformista de Altenstein e Hardenberg e chega a dedicar um exemplar da Filosofia do Direito ao ministro reformador Hardenberg, que falece em 1822 sem ver a Prússia com uma constituição e com a reforma das suas instituições e leis incompletas. Segundo Rosenfield, Hegel não teve muita sorte quando chegou a Berlim, pois no exato momento em que inicia sua trajetória acadêmica e pública na Prússia é que se inicia o fim da reforma prussiana e o reestabelecimento do poder absoluto do Rei da Prússia e da manutenção dos privilégios nobiliárquicos.

Nesse sentido, pode-se dizer que Hegel teve pouca sorte, pois, no momento em que se torna figura pública, logo Reitor da Universidade de Berlim, o ocaso dos reformadores é definitivo. Ele teve de conviver com a Restauração, sentindo a desconfiança do Imperador em relação a si, não tendo usufruído plenamente dos benefícios de uma liberdade (ROSENFIELD, 2011, p. 88).

Portanto, a afirmação de que Hegel era o filósofo oficial do Estado prussiano deve ser feita com muita cautela. Essa afirmação é em certa medida verdadeira, caso o Estado a cujo juízo se refira seja o Estado administrado pelos reformadores prussianos, e é em certa medida falsa, caso se refira ao Estado prussiano governado autocraticamente por Guilherme III $^{8}$. Mas de tudo que foi dito podemos concluir que Hegel compartilhava com personalidades como Altenstein, Hardenberg e Thibaut o desejo de "racionalizar" as normas e

\footnotetext{
${ }^{8}$ Segundo Raymond Plant "as acusações levantadas desde que Hegel se tornou em algum sentido o filósofo oficial da Prússia têm de ser tratadas com algum cuidado. As instituições da Prússia que ele defendeu depois de sua nomeação foram aquelas que emergiram das reformas de Altenstein e Hardenberg" (PLANT, 2000, p. 18).
} 
instituições positivas da Prússia contra os privilégios da Coroa e da alta nobreza que havia sido incapaz de defender a Prússia da invasão francesa9 .

\section{III}

A partir de tudo que foi dito até agora é evidente que Hegel não pode de modo algum ser classificado como um pensador conservador, ou muito menos reacionário, mas como um teórico político reformista. O julgamento de Hegel sobre as revoluções e reformas da modernidade e da pré-modernidade, demonstram que Hegel toma partido pelos defensores das grandes transformações, seja dos reformistas ou dos revolucionários, sejam transformações efetuadas pelos "de cima", como Richelieu na França, sejam as efetuadas pelos "de baixo", como o povo na Revolução Francesa. O que importa para Hegel é que as normas e instituições positivas sejam corrigidas atendendo as exigências normativas da racionalidade, isto é, quando em um determinado contexto histórico-social mudanças são necessárias, todos aqueles que defendem as mudanças estão do lado da razão e os que estão contra as mudanças, lutando para conservar as coisas como estão, apesar da situação está insustentável, Hegel considera contrário às prescrições da razão, são instrumentos do atraso.

Em seus escritos sobre a história Hegel louvou todas as revoluções e reformas que geraram a modernidade. A avaliação de Hegel sobre a revolução francesa é de conhecimento público e notório: explicou e justificou esse acontecimento "histórico-mundial". Hegel viu na Revolução Francesa o início de um novo período histórico, de efetividade da razão ${ }^{10}$ e considerou o Estado moderno como um resultado inegável da revolução de 1789, Estado fundado e mantido a partir dos princípios reitores do Direito racional. Enquanto Hegel saúda as realizações a oeste do Reno, o movimento político restauracionista condena em uníssono a Revolução Francesa e seus ideais tanto do ponto de vista político, como um ultrajante desrespeito das leis e instituições positivas e a classe dos "melhores" (os aristocratas) e também do ponto de vista religioso, condenando a revolução como uma expiação dos pecados da humanidade, um castigo de Deus, e até mesmo Napoleão é definido como um anticristo (LOSURDO, 1998, p. 154-155).

\footnotetext{
9 Segundo Rosenfield, quando os exércitos napoleônicos invadiram a Prússia, diversos generais que tinham essas altas patentes não por mérito, mas por herança ou por seu título de nobreza, entregaram sem lutar diversos locais estratégicos, como pontes, fortes e castelos que serviam como base militar. Os militares que venceram Napoleão e libertaram a Prússia, eram na sua grande maioria militares de carreira, haviam conseguido suas patentes por mérito e por isso defendiam a reformas das leis e instituições prussianas. Para esses reformadores, havia sido justamente o atraso e a nobreza feudal os responsáveis pela humilhante derrota diante dos franceses (ROSENFIELD, 2011, p. 96-98).

10 "Nunca desde que o sol começou a brilhar no firmamento e os planetas começaram a girar ao seu redor se havia percebido que a existência do homem está centrada em sua cabeça, isto é, no pensamento, a partir do qual ele constrói o mundo real. Anaxágoras foi o primeiro a dizer que o nôus rege o mundo; mas só agora o homem percebeu que o pensamento deve governar a realidade espiritual. Assim se deu um glorioso amanhecer. Todos os seres vivos pensantes comemoraram essa época" (HEGEL, 2008, p. 366).
} 
Sobre as outras duas revoluções que são consideradas, pela maior parte dos historiadores como parteiras da modernidade, a saber, a revolução inglesa e a revolução americana (Independência dos Estados Unidos), o julgamento de Hegel também é positivo, ambas são consideradas como historicamente necessárias e seus resultados são tidos como progressistas, i.e., bons. Hegel classificou as três grandes revoluções que inauguraram a modernidade e a contemporaneidade, a francesa, inglesa e americana, como realizações históricas da liberdade objetiva.

Em relação ao processo de Independência dos Estados Unidos, Hegel censura a Inglaterra como um ator histórico conservador, e por isso um entrave à realização da liberdade, e por sua vez elogia a coragem e entusiasmo das milícias norte americanas que lutavam pela liberdade em frente a um bem equipado e poderoso exército profissional, e mesmo assim foram capazes de derrotá-lo, fazendo a roda da história girar ${ }^{11}$. Por sua vez, enquanto condena o Estado inglês no contexto da Revolução Americana, no contexto da Revolução Inglesa Hegel condena o Rei (!) e aprova e justifica a luta do povo contra a coroa, pois era, na sua avaliação, a luta de um princípio da liberdade contra um direito positivo contrário às expectativas da razão (o poder absoluto do Rei e a tese da origem divina do direito), ou seja, o monarquista Hegel apoiou forças antimonarquistas no acontecimento histórico-mundial de 1642-1651. Ao mesmo tempo, como todo reformista, criticou a radicalização dos niveladores (Levellers) que exigiam o sufrágio universal masculino e uma sociedade de pequenos proprietários e saudou a pax política de Oliver Cromwell e suas reformas modernizadoras,

Contra a asserção da perfeição do poder absoluto, do poder segundo o qual os reis só deviam prestar contas a Deus (ou seja, ao confessor) o povo fanático sublevou-se e alcançou, no confronto do catolicismo exterior com o puritanismo, o âmago da interioridade, que se esvaía num mundo objetivo - em parte elevando-se fanaticamente; em parte, mostrando-se ridiculamente incongruente. Esses fanáticos, como também os de Müntzer, queriam governar o Estado, imediatamente, baseados no temor de Deus, como igualmente fanáticos eram os soldados que tinham que rezar enquanto defendiam sua causa no campo de batalha. Todavia, um líder militar tinha força - e com isso o governo - nas mãos; pois tem-se que governar o Estado. Cromwell sabia o que era governar. Assim ele se tornou o senhor e expulsou aquele parlamento que vivia rezando (HEGEL, 1998, p. 358).

Hegel também elogia a resistência política e militar da Holanda protestante contra a Espanha católica ${ }^{12}$, afirmando que a Holanda representava a causa da liberdade contra a Espanha e seus princípios conservadores e mesmo reacionários, pois na época a Holanda era uma nação que respeitava (na

11 "As milícias do Estado livre da América do norte mostraram-se tão valentes nas lutas pela libertação quanto os holandeses sob Filipe II” (Ibidem, p. 78).

12 "A Bélgica ainda se dedicava à religião católica, e permaneceu sob o domínio espanhol; a Holanda, ao contrário, defendeu-se heroicamente de seus opressores" (HEGEL, 1998, p. 358). 
avaliação de Hegel) a liberdade religiosa, a liberdade de pensamento e de expressão (pautas políticas racionais e, por isso, libertárias), enquanto a Espanha era católica, absolutista e obscurantista. Também são famosas as declarações de Hegel sobre o caráter emancipatório do cristianismo no final da antiguidade (Ibidem, p. 271-283) e o valor histórico da reforma protestante para a gênese da modernidade e sua preparação das condições subjetivas da Revolução Francesa (Ibidem, p. 362-364), para Hegel a realização prática dos ideais da reforma.

Hegel também condenou a escravidão como uma instituição injustificável, contrária aos direitos da razão, classificando em sua filosofia da história a maioria das rebeliões escravas (das antigas às modernas) como uma luta da dignidade humana contra o direito positivo ${ }^{13}$. Hegel também apoiou as lutas de independência das colônias latino-americana, admirava o esforço desses povos em construírem seus próprios Estados se organizando racionalmente, em síntese, "portanto, não existe revolução na história da humanidade que não tenha sido apoiada e celebrada por esse filósofo que também tem fama de ser um incurável homem da ordem (grifo nosso)" (LOSURDO, 1998, p. 155).

Apesar do elogio e justificativa que Hegel faz das revoluções e das transformações radicais e violentas do status quo (como foram as revoluções inglesa, americana e francesa), o filósofo alemão é um homem politicamente reformista, entre uma revolução armada, com mudanças imediatas, e uma reforma pacífica, com mudanças lentas e graduais, a última é preferível. O "silogismo político" que Hegel elabora em sua Filosofia do Direito é S-P-U, isto é, singular, particular e universal, sendo o termo maior o singular que para Hegel é a figura do príncipe, o poder decisório de fato, aquele a quem cabe à soberania. O monarquismo de Hegel lhe faz confiar ao príncipe o direito e prerrogativa de efetuar as mudanças necessárias no Estado, permitindo que o direito racional torne-se positivo ${ }^{14}$. No seu último escrito político, em 1831, Hegel defende as vantagens da "via prussiana" para efetivar as "ideias que formam a base da verdadeira liberdade" (HEGEL, 2009, §29). Diz o filósofo:

$\mathrm{Na}$ França, essas ideias têm se misturado com muitas outras abstrações e se associado com focos de violência com as quais estamos todos familiarizados, ao passo que na Alemanha, de forma menos alterada, essas ideias a muito que se tornaram princípios firmes da convicção interior e da opinião pública, e produziram uma transformação real - pacífica, gradual, e lícita - das antigas relações jurídicas. Assim, já ocorreu um grande progresso aqui na institucionalização da liberdade real; nós agora terminamos os trabalhos mais essenciais e desfrutamos dos seus frutos [...] (Ibidem, \$29).

\footnotetext{
13 A radicalidade da perspectiva antiescravista de Hegel, que não podemos saber se foi ou não um abolicionista, é melhor compreendida quando contextualizada. No final do século XVIII e início do século XIX a escravidão era regra, uma instituição aceita como "natural", o próprio Napoleão reestabeleceu a escravidão nas colônias francesas em 1802, apesar da sua abolição pelos jacobinos, a Inglaterra aboliu a escravidão apenas em $1853 \mathrm{com}$ o Slavery aboliction act e a Santa Aliança lutava contra todo e qualquer movimento e projeto liberal, sendo a abolição da escravidão umas dessas pautas. Nesse contexto adverso, a defesa, mesmo que tímida, de Hegel do fim da escravidão é uma atitude teórica ousada.

${ }^{14} \mathrm{O}$ monarquismo de Hegel é um dos motivos do mesmo ter sido acusado de conservador.
} 
Hegel via nos parlamentos e assembleias de seu tempo a importância e influência política decisiva da aristocracia ${ }^{15}$ e, em geral, o parlamento era usado, na perspectiva hegeliana, como um instrumento das forças conservadoras e mesmo como um bastião da reação ${ }^{16}$ contra as reformas promovidas pela coroa, o que deixava como única alternativa histórica a revolução. Essa seria a conturbada situação inglesa devido os impasses de 1831.

Para Hegel as forças históricas progressistas eram aquelas que defendiam os interesses universais da razão contra os direitos particulares positivos, isto é, defendiam os interesses gerais contra os privilégios particulares. Nesse sentido, estava implícito nos gritos que exigiam "liberdade" nos parlamentos e nos programas políticos anticentralistas e federalistas, diversos interesses particulares, das camadas político-sociais conservadoras que eram beneficiárias do status quo e por isso eram contrárias a qualquer tentativa de correção do direito positivo, pois se beneficiavam do atraso, diz Hegel,

Quando se fala de liberdade, deve-se atentar para o fato se tratar de interesses particulares, pois, quando se tirou da nobreza o seu poder soberano, aos cidadãos restaram ainda a obediência, a servidão e a subordinação aos aristocratas, em parte por não estarem capacitados a assumir a propriedade, e em parte por estarem sobrecarregados com o serviço e não poderem vender livremente $\mathrm{o}$ seu produto. Havia interesse por essa libertação tanto por parte do poder estatal quanto dos súditos [...]. A aristocracia da posse é contra ambos, contra o poder estatal e contra os indivíduos (HEGEL, 2008, p. $355) .{ }^{17}$

Segundo Domenico Losurdo, "a tomada de posição de Hegel podia e talvez possa ainda escandalizar os ambientes liberais, mas encontra o consenso de Lenin, que nela divisa os 'germes do materialismo histórico', pela devida atenção reservada às 'relações de classe"” (LOSURDO, 1998, p. 157). O discurso liberal tende a acusar de autoritário tudo o que é crítico ao parlamentarismo e a

15 No artigo sobre a reforma eleitoral britânica Hegel constata que a autoridade política da nobreza é tamanha que no parlamento britânico com facilidade são aprovadas leis contrárias aos interesses da coroa e do povo e dificilmente aprovadas ou mesmo postas em votação leis contrárias aos interesses nobiliárquicos, isto é, facilmente na "liberal" Inglaterra eram aprovadas leis antimonárquica e antipopulares, mas havia uma dificuldade tremenda de ao menos se votar leis antiaristocráticas. Segundo Hegel "o elemento aristocrático é um poder extremamente importante na Inglaterra” (HEGEL, 2009, \$3). E que justamente por isso o direito positivo britânico seria um dos menos racionais e por isso um dos mais atrasados da Europa, "A Inglaterra tem ficado tão vergonhosamente atrás dos outros Estados civilizados da Europa em relação às suas instituições baseadas no verdadeiro direito, pela simples razão de que o poder do governo está nas mãos daqueles que possuem tantos privilégios que contradizem a lei constitucional racional e uma genuína legislação" (Ibidem, \$6).

${ }^{16}$ Hegel refere-se principalmente aos casos da Inglaterra, Würtemberg e da Polônia.

17 Para Hegel nos Estados em que o rei se aliou ao povo enfrentou a aristocracia e efetuou as correções do direito positivo atendendo as demandas da razão, por sua vez, onde o rei se aliou à aristocracia manteve os privilégios, na forma de direito positivo, intocados. Diz Hegel, "os reis, então, apoiados pelos povos, venceram a classe dos injustos. No entanto, onde os reis se apoiam nos barões - ou onde estes afirmaram a sua liberdade perante os reis -, lá permaneceram os direitos positivos ou injustiças" (HEGEL, 2008, p. 355). 
defesa dos interesses particulares, e não seria diferente em relação a Hegel, autor ao qual a tradição liberal é declaradamente hostil. ${ }^{18}$ Para Hegel era necessário identificar nos diversos discursos e práticas políticas os verdadeiros objetivos. Interessava a Hegel distinguir quais demandas favoreciam ao todo e quais demandas favoreciam apenas a grupos particulares específicos da comunidade, "os poderosos barões pareciam ser o centro, propagando a liberdade, mas, na verdade, eles só defendiam os seus privilégios perante o poder real e perante os cidadãos" (HEGEL, 2008, p. 354).

Hegel tinha consciência, como arguto observador da história que em diversas ocasiões os interesses universais tinham que ser impostos através da força, pois esbarravam em fortes e estabelecidos privilégios instituídos como direitos positivos. No seu contexto histórico esses "direitos positivos" eram os da aristocracia agrária hostil às exigências históricas da razão (Estado unificado, constituição e industrialização) ${ }^{19}$. Para evitar a realização da razão pelos "de baixo", a chamada "solução francesa", Hegel tentava demonstrar o valor da "solução prussiana" para a realização da razão e por tanto das correções necessárias do direito positivo. Isto é, seria preferível para todos, até para os aristocratas (estamento cujo direito exclusivo de compor a câmara alta e como suporte da monarquia Hegel defende ${ }^{20}$ ) que a realização da razão fosse efetivada por cima, pelo príncipe, o que evitaria os perigos da radicalização política, como foi o terror jacobino, que Hegel condena e teme como solução política dos problemas históricos.

A modernidade para Hegel era um período de profundas transformações históricas, pela primeira vez na história os homens estavam agindo de acordo com a razão, a realidade parecia girar ao redor da racionalidade $e$ progressivamente a liberdade se efetivava em normas e instituições cada vez mais racionais. Nesse contexto era necessário efetivar as mudanças necessárias para o progresso da razão, tais mudanças, como já dissemos, seriam feitas pelos "de baixo" ou pelos "de cima", de modo que para evitar todos os constrangimentos de uma revolução, Hegel aconselhava a reforma como a forma mais eficiente e moderada de realizar a razão. Entretanto, para Hegel essas mesmas reformas poderiam exigir decisões e medidas despóticas como as de Cromwell, Napoleão e Richelieu, pois a resistência conservadora dos setores sociais privilegiados (que na época de Hegel significa a aristocracia) poderia ser obstinada e somente através de medidas duras essa resistência poderia ser quebrada. Não só Hegel reconhecia a necessidade de medidas severas contra os setores sociais conservadores para a realização das mudanças necessárias exigidas pela razão,

\footnotetext{
${ }^{18}$ Vide o tratado do autor liberal Karl Popper A sociedade aberta e seus inimigos, no qual Platão, Hegel e Marx são acusados de inimigos da liberdade. Segundo Popper, "quando em 1815, o partido reacionário começou a retomar o poder na Prússia, achou-se na extrema necessidade de uma ideologia. Hegel foi indicado para suprir essa necessidade e ele o fez revivendo as ideias dos primeiros grandes inimigos da sociedade aberta: Heráclito, Platão e Aristóteles. (...). A significação histórica de Hegel pode ser vista no fato de representar ele o 'elo perdido', por assim dizer, entre Platão e a forma moderna de totalitarismo" (grifo nosso) (POPPER, 1974, p. 37).

${ }^{19}$ Aquilo que a historiografia e a sociologia denominarão de "modernização".

20 "A aristocracia deve cumprir o seu dever de ser o suporte do trono, trabalhando para o Estado e para o universal [...]” (HEGEL, 2008, p. 355).
} 
mas diversas figuras públicas e teóricos da época reconheciam que as camadas sociais privilegiadas não fariam concessões espontaneamente. Essas medidas "despóticas" a que algumas vezes Hegel se refere na Filosofia da História, como as do cardeal Richelieu ou as de Napoleão "tinha[m] como alvo os 'direitos privados' e os privilégios da tradição feudal” (LOSURDO, 1998, p. 158). ${ }^{21}$

IV

Refletindo sobre a conjuntura política inglesa em meio aos debates sobre a proposta de reforma eleitoral, Hegel critica a limitação do poder do Rei no Direito positivo inglês. No contexto inglês diversas contradições estavam se radicalizando, a contradição entre a Igreja Anglicana e o catolicismo irlandês, a contradição entre os interesses dos camponeses e os interesses da nobreza agrária, da nobreza e da burguesia, do parlamento e da coroa, do povo e do parlamento, enfim, diversas contradições estavam se acentuando e a contradição das contradições, a existente entre o universal e o particular estava latente. Diante desse quadro três "sujeitos" poderiam realizar as mudanças necessárias e solucionar as contradições: o parlamento, o Rei e o povo. O parlamento não representava para Hegel um sujeito capaz de fazer o que tinha que ser feito, na sua perspectiva o parlamento era um antro de interesses particulares. Apenas o Rei ou o povo estariam dispostos e seriam capazes de efetivar as demandas da razão. Porém, na Inglaterra o preconceito e desconfiança públicos em relação à coroa e seu diminuto e quase inexistente poder inviabilizavam a realização da razão pela "via prussiana", de modo que a Inglaterra da época estaria, na avaliação de Hegel, diante das portas da revolução. Afinal, fora o rei, "o outro poder que seria capaz de realizar a transformação seria o do povo" (HEGEL, 2009, 134) e, nessas circunstâncias, caso seja deixada ao povo a missão de realizar as mudanças necessárias "não se inauguraria uma reforma, mas uma revolução" (Ibidem). Apesar de o texto terminar censurando a limitação exacerbada do poder monárquico na Inglaterra, o que inviabilizaria a reforma e deixaria como única opção a revolução, Hegel não crítica a possibilidade (e talvez necessidade) de uma revolução, mas lamenta que a reforma seja quase impossível.

Hegel defendia que, sempre que os interesses particulares se sobrepunham aos interesses universais, a situação era injustificável, que do ponto de vista histórico todos os períodos de decadência da história humana foram os que os interesses particulares se sobrepuseram aos universais. Na Filosofia da História Hegel parece identificar os períodos históricos em que a aristocracia governou, como Império Romano, Idade média, etc., como os períodos de

${ }^{21} \mathrm{Em}$ 1831, Hegel irá afirmar que o fim dos privilégios da aristocracia era um pré-requisito indispensável para o progresso da liberdade, contrariando a tese dos conservadores e reacionários que diziam que a abolição das normas e instituições tradicionais, como demonstrou o exemplo francês, conduziriam necessariamente a anarquia. Diz Hegel, "é de conhecimento comum, não só que esses direitos tenham desaparecido em outros Estados sem tais consequências, mas também que a abolição tem sido considerada como uma base importante de aumento da prosperidade e liberdade essencial" (HEGEL, 2009, \$9). 
decadência e obscuridade, quando os cargos públicos e mesmo o Estado foram reduzidos à condição de propriedade privada de alguns que impõem seus interesses privados em detrimento do interesse público, por exemplo, na idade média, quando o "Estado" foi dividido em diversas propriedades nobiliárquicas, os feudos, e os cargos públicos eram vendidos pelos seus "proprietários". Na modernidade o despotismo esclarecido, iluminismo e revoluções foram os meios que a razão encontrou para se efetivar, restituindo os direitos do universal contra os privilégios particulares, "absolutismo iluminado e revolução francesa são duas etapas de um único processo revolucionário que levou a destruição do feudalismo e ao nascimento do Estado moderno, portanto, do processo da liberdade" (LOSURDO, 1998, p. 159). ${ }^{22}$ Em síntese, para Hegel foram as reformas e revoluções que fizeram o Estado moderno surgir e se desenvolver, inaugurando um novo estágio histórico da liberdade.

\section{CONCLUSÃO}

A filosofia prática de Hegel não é uma apologia do status quo autoritário ou totalitário, como foi acusada por certos círculos e autores liberais como Rudolf Haym e Karl Popper, nem como erroneamente entenderam alguns setores do marxismo (mesmo Marx e Engels). A filosofia prática de Hegel é uma teoria crítica das normas e instituições positivas, uma teoria crítica da realidade estabelecida, especificando os critérios de avaliação e correção do Direito positivo e se filiando a soluções reformistas, sem negar a possibilidade e às vezes mesmo a necessidade da revolução como forma de corrigir a realidade fática de acordo com as exigências da razão prática. A filosofia de Hegel, na sua dimensão prática, "não serve então como uma racionalização acrítica do status quo, mas sim como o pressuposto necessário a uma genuína teoria racional das instituições históricas e contemporâneas" (DUDLEY, 2013, p. 246, grifo nosso). Não é por acaso que Marcuse na obra Razão e Revolução defenderá que Hegel é o fundador da teoria social contemporânea.

\section{REFERÊNCIAS BIBLIOGRÁFICAS}

DUDLEY, Will. Idealismo alemão. Tradução Jacques A. Waimberg. Petrópolis, RJ: Vozes, 2013.

\footnotetext{
${ }^{22}$ Não por acaso, devido à hostilidade explícita de Hegel à aristocracia, Domenico Losurdo (1998, p. 150-158) afirma que Hegel foi um pensador plebeu, isto é, filiado aos interesses e posições plebeias, incluído aqui tanto o povo strictu sensu, quanto a burguesia, em síntese, todos os não nobres (o terceiro estado). A hostilidade de Kant, republicano, é mais radical que a de Hegel, monarquista. Enquanto Hegel reconhece a necessidade da existência da nobreza e defende a prerrogativa aristocrática de preencher vagas na câmara alta, Kant define a nobreza como um erro, uma anomalia e que o Estado deveria, para acabar com essa classe de pessoas, deixar que essa classe decline e não sejam mais concedidos títulos de nobreza a mais ninguém, nem mesmo aos filhos dos nobres. Diz Kant, "o único meio pelo qual o Estado pode, então, gradualmente corrigir esse erro por ele cometido, o de conceder privilégios hereditários contrários ao direito, é deixar que declinem e não preencham vagas nessas posições” (KANT, 2008, p. 172).
} 
HEGEL, G. W. F. On the English Reform Bill. In: Political writings. Trans. H.B. Nisbet. Cambridge University Press: New York, 2009.

Filosofia da História. Tradução de Hans Hardem e Maria Rodrigues. 2. ed. Brasília: Editora UNB, 2008.

Linhas fundamentais da Filosofia do Direito. Tradução de Paulo Menezes et al. 2. ed. São Leopoldo, Rio Grande do Sul: Editora Unisinos, 2010.

KANT, Immanuel. A metafísica dos costumes. Tradução, textos adicionais e notas: Edson Bini. 2. ed. rev. Bauru, SP: EDIPRO, 2008.

LOSURDO, Domenico. Hegel, Marx e a tradição liberal: liberdade, igualdade e Estado. Tradução Carlos Alberto Fernando Nicola Dastoli. São Paulo: EDUNESP, 1998.

MARCUSE, Herbert. Razão e revolução: Hegel e o advento da teoria social. Tradução Marília Barroso. Rio de Janeiro: Paz e Terra, 1978.

PLANT, Raymond. Hegel. Sobre religião e filosofia. Tradução Oswaldo Giacóia. São Paulo: Editora UNESP, 2000.

POPPER, Karl. A sociedade Aberta e seus inimigos. Vol. 2. Tradução de Milton Amado. São Paulo: Editora Itatiaia, Editora da Universidade de São Paulo, 1974.

ROSENFIELD, Denis. Hegel. 2. ed. Rio de Janeiro: Jorge Zahar Editor, 2005.

ROSENFIELD, Denis. Qual liberdade? Hegel e os reformadores prussianos. Revista Ágora Filosófica, ano 11, n. 1, p. 81-99, jan./jun. 2011. 